\title{
Clinical and laboratory findings of multisystem inflammatory syndrome in children (MIS-C) below age 1
}

\author{
Sadık Yurttutan ${ }^{1}$ • Utku Ufuk Güllü ${ }^{2}$ - Sevcan İpek ${ }^{3}$ - Sukru Gungorr ${ }^{4}$ Nursel Yurttutan ${ }^{5}$
}

Received: 5 March 2021 / Revised: 16 March 2021 / Accepted: 17 March 2021 / Published online: 25 March 2021

(C) International League of Associations for Rheumatology (ILAR) 2021

We read the article by Ozsurekci and colleagues with great interest [1]. The article examines the clinical and laboratory characteristics of 30 multisystem inflammatory syndrome in children (MIS-C) cases and provides valuable data for the literature. MIS-C is a clinical entity that develops secondary to immune dysregulation after contracting SARS-CoV-2.

The article's discussion part refers to the literature, which describes that MIS-C develops a few weeks following exposure [1]. It is speculated that SARS-CoV-2 could have a more symptomatic course in infants below the age of 5 . Furthermore, there is no data pertaining to the correlation between age and the severity of disease in MIS-C. There is also no data regarding the time of onset of MIS-C symptoms after SARS-CoV-2 exposure according to age in pediatric patients.

It has been speculated that MIS-C may have a varying course in children according to age. This may be because the risk of developing immune dysregulation can vary across different age groups in children. The article by Ozsurekci and colleagues does not contain any information regarding the severity and duration of developing MIS-C according to age groups. All cases mentioned in the article are above the age of

Sadık Yurttutan

dryurttutan@gmail.com

1 Department of Pediatrics, Division of Neonatology, Faculty of Medicine, SUA Hospital, KSU University, Kahramanmaraş, Turkey

2 Department of Pediatrics, Division of Pediatric Cardiology, Faculty of Medicine, SUA Hospital, KSU University, Kahramanmaraş, Turkey

3 Department of Pediatrics, Division of Pediatric Intensive Care Unit, Faculty of Medicine, SUA Hospital, KSU University, Kahramanmaraş, Turkey

4 Department of Pediatrics, Division of Pediatric Gastroenterology, Faculty of Medicine, SUA Hospital, KSU University, Kahramanmaraş, Turkey

5 Department of Radiology, Faculty of Medicine, SUA Hospital, KSU University, Kahramanmaraș, Turkey
1. There are a limited number of publications regarding the clinical course and laboratory findings of MIS-C in cases below age 1 [2]. While other age groups may exhibit typical symptoms such as fever, rash, respiratory distress, and gastrointestinal symptoms, cases below the age of 1 may present with more uncommon symptoms such as febrile convulsion, persistent pulmonary hypertension and coronary artery aneurysm.

In this regard, we would like to present 10 MIS-C cases below age 1 diagnosed and monitored in our clinic. The mean age of these patients is 90 (6-245) days. The most common symptoms were fever and rash (in 80\%), vomiting and feeding inability (in $30 \%$ ), and respiratory distress (in 20\%). Febrile convulsion and diarrhea were each observed in 1 patient. Six cases tested positive for SARS-CoV-2 IgG. There were 6 cases exhibiting a clinically significant increase in $C$-reactive protein $(C R P)$.

Comorbidity was present in $50 \%$ of the cases. Two cases with comorbidity died. These cases were affected by a ventricular septal defect and an aortic outflow obstruction of moderate severity. On the topic of the patients' medical history, the mean time interval between contact exposure to SARS-CoV-2 and the onset of symptoms was 10.6 (4-16) days.

Cases under the age of 1 may exhibit a varying immune response due to antibodies from the mother, vaccine exposure and effective thymus activity [3]. Compared to other age groups, these patients may present with different clinical and laboratory findings and may have a varying time of onset. Our patient group demonstrated an early time of onset for MIS-C following SARS-CoV-2 exposure. It should be considered that there may be a difference particularly in disease severity, systems involved and time of MIS-C onset. In the article by Ozsurekci and colleagues, if there is a difference between the age groups in terms of MIS-C severity, degree of involvement, and time of onset, emphasizing this difference will inform the reader on the clinical course of the disease.

We believe that investigating the presentation of MIS-C in different age groups will aid in diagnosing the disease, predicting the clinical course and planning approaches for treatment.

Best regards 


\section{Declarations}

Disclosures None.

\section{References}

1. Ozsurekci Y, Gürlevik S, Kesici S, Akca UK, Oygar PD, Aykac K, Karacanoglu D, Sartas Nakip O, Ilbay S, Katlan B, Cengiz AB, Basaran O, Cura Yayla BC, Karakaya J, Bilginer Y, Bayrakci B, Ceyhan M, Ozen S (2021) Multisystem inflammatory syndrome in children during the COVID-19 pandemic in Turkey: first report from the Eastern Mediterranean. Clin Rheumatol 12:1-11. https://doi.org/ 10.1007/s10067-021-05631-9

2. Feldstein LR, Tenforde MW, Friedman KG, Newhams M, Rose EB, Dapul H, Soma VL, Maddux AB, Mourani PM, Bowens C, Maamari M, Hall MW, Riggs BJ, Giuliano JS Jr, Singh AR, Li S, Kong M,
Schuster JE, McLaughlin GE, Schwartz SP, Walker TC, Loftis LL, Hobbs CV, Halasa NB, Doymaz S, Babbitt CJ, Hume JR, Gertz SJ, Irby K, Clouser KN, Cvijanovich NZ, Bradford TT, Smith LS, Heidemann SM, Zackai SP, Wellnitz K, Nofziger RA, Horwitz SM, Carroll RW, Rowan CM, Tarquinio KM, Mack EH, Fitzgerald JC, Coates BM, Jackson AM, Young CC, Son MBF, Patel MM, Newburger JW, Randolph AG, Overcoming COVID-19 investigators (2021) Characteristics and outcomes of US children and adolescents with multisystem inflammatory syndrome in children (MIS-C) compared with severe acute COVID-19. JAMA. https://doi.org/10.1001/jama.2021.2091

3. Güneș H, Dinçer S, Acıpayam C, Yurttutan S, Özkars MY (2021) What chances do children have against COVID-19? Is the answer hidden within the thymus? Eur J Pediatr 180(3):983-986. https://doi. org/10.1007/s00431-020-03841-y

Publisher's note Springer Nature remains neutral with regard to jurisdictional claims in published maps and institutional affiliations. 